\title{
Epidemiology of thermotolerant Campylobacter infection in poultry in Nsukka agricultural zone, Nigeria
}

\author{
Emmanuel Okechukwu Njoga, Innocent Okwundu Nwankwo and Joel Chukwudi Ugwunwarua \\ Department of Veterinary Public Health and Preventive Medicine, Faculty of Veterinary Medicine, University of Nigeria, \\ Nsukka, Enugu State, Nigeria. \\ Corresponding author: Innocent Okwundu Nwankwo, e-mail: innocent.nwankwo@unn.edu.ng \\ Co-authors: EON: njoga.emmanuel@unn.edu.ng, JCU: darljoel88@gmail.com \\ Received: 19-08-2019, Accepted: 07-11-2019, Published online: 19-12-2019
}

doi: www.doi.org/10.14202/IJOH.2019.92-98 How to cite this article: Njoga EO, Nwankwo IO, Ugwunwarua JC. Epidemiology of thermotolerant Campylobacter infection in poultry in Nsukka agricultural zone, Nigeria. Int J One Health 2019;5:92-98.

\begin{abstract}
Background and Aim: Thermotolerant Campylobacter organisms (TCOs) are primary causes of bacterial foodborne gastroenteritis worldwide. Although all warm-blooded animals are susceptible to colonization by TCOs, food-producing animals, especially poultry, are major reservoirs of the infection for transmission to humans. This epidemiological study for thermotolerant Campylobacter infection (TCI) in poultry was, therefore, conducted to determine the prevalence and to identify the risk factors of TCI in 60 randomly selected poultry farms in Nsukka agricultural zone.

Materials and Methods: A structured questionnaire was used to elicit information on the farmers' involvement in practices that may aggravate TCI in poultry farms. Isolation of TCOs for the determination of prevalence of the infection was done following standard microbiological protocol.

Results: The majority $(93.3 \%)$ of the farms practiced intensive management system. Farm and individual prevalence of TCI were $78.3 \%$ and $19.4 \%$, respectively. The prevalence of $15.7 \%$ and $23.6 \%$ was recorded for birds reared in urban and rural areas, respectively. Similarly, prevalence rates of $17.2 \%, 25 \%, 14.7 \%$, and $24.5 \%$ were documented for broiler, layer, male, and female birds, respectively. Major risk factors of TCI found were non-sanitization of drinking water, rearing birds of different ages together, thinning, raising other animals alongside poultry, and overstocking.
\end{abstract}

Conclusion: Overall prevalence of $19.4 \%$ is high from public health and food safety points of view. Farmers' participation in the risk factors for TCI is massive. Significant improvement in biosecurity practices in poultry farms in the study area is therefore imperative; to limit TCI in poultry and hence the risk of human infection through the food chain or at the poultryhuman interface.

Keywords: biosecurity, Nigeria, poultry, public health, risk factors, thermotolerant Campylobacter infection.

\section{Introduction}

Thermotolerant Campylobacter organisms (TCOs) are major threats to public health, being the predominant causes of bacteria foodborne illnesses in both developed [1] and developing [2] countries. The organisms are Gram-negative bacteria belonging to the family Campylobacteraceae and genus Campylobacter [3]. Campylobacters are small (0.2-0.9 $\mu \mathrm{m}$ wide and 0.5-6.0 $\mu \mathrm{m}$ long) and rod shaped [4], although coccoid or spherical-shaped forms are usually found in old or stress-exposed cultures, as viable but non-culturable cells. The TCOs, especially Campylobacter jejuni, are highly infective, requiring just about 500 cells to produce disease in humans [5].

Although members of the genus Campylobacter consist of 32 validly described species and 13 subspecies [4-6], the thermophilic species are the most

Copyright: Njoga, et al. This article is an open access article distributed under the terms of the Creative Commons Attribution 4.0 International License (http://creativecommons.org/licenses/ by/4.0/), which permits unrestricted use, distribution, and reproduction in any medium, provided you give appropriate credit to the original author(s) and the source, provide a link to the Creative Commons license, and indicate if changes were made. The Creative Commons Public Domain Dedication waiver (http:// creativecommons.org/ publicdomain/zero/1.0/) applies to the data made available in this article, unless otherwise stated. important members of the genus from food safety and public health points of view. Their complicity in colonization of food-producing animals at farms and ease of transmission of the pathogens to humans through the food chain $[7,8]$ makes the organisms essential zoonotic agents. Although, all food animals can be reservoirs of thermotolerant Campylobacter infection (TCI), poultry are the undisputable major reservoirs of the organisms, due to heavy colonization of their gastrointestinal tracts (GIT) early in life through horizontal transmission $[6,9]$. The predilection of TCOs for poultry GIT may be due to the similarity in the temperature growth requirement of the organisms $\left(42 \pm 1^{\circ} \mathrm{C}\right)$ and the physiological temperature of poultry $\left(42 \pm 1^{\circ} \mathrm{C}\right)$.

Transmission of TCOs in both animals and humans proceeds essentially through the feco-oral route. Humans usually acquired the infection through consumption of infected raw or undercooked foods of animal origin, especially poultry $[10,11]$. In addition, unhygienic food preparation practices and contamination of ready-to-eat foods with raw chicken are major sources of the infection and means of transmission of Campylobacter in humans [3,10,11]. Moreover, close contact with infected birds may facilitate the 
spread of the infection, especially among occupationally exposed (poultry farmers, live bird sellers, and poultry carcass processors) and immunologically naive or compromised (pregnant women and children under 5 years of age) individuals [12]. Extensive husbandry systems of food animal production and animal-human cohabitation in rural settings enhance intra- and inter-species transmission of Campylobacter organisms $[13,14]$.

Human campylobacteriosis develops approximately $1-5$ days post-infection $[1,15]$ and is characterized by gastrointestinal problems such as nausea, vomiting, diarrhea, dysentery, headache, fever, abdominal cramps, and myalgia. Although, mortality rate associated with campylobacteriosis is low and infections may resolve without antibiotic treatment $[8,16]$, the organisms cause severe debilitating illnesses and infrequent fatal complications in humans, such as Guillain-Barré syndrome, reactive arthritis, Reiter's syndrome, irritable bowel syndrome, inflammatory bowel disease, Crohn's disease, ulcerative colitis, hemolytic uremic syndrome, and meningitis $[17,18]$.

Food safety concerns for campylobacteriosis have grown rapidly due to frequent isolation of antimicrobial-resistant thermophilic Campylobacter strains in food-producing animals, especially poultry $[3,8,19,20]$; and the ease of transmission of this zoonosis and/or the antimicrobial-resistant organisms through consumption of the contaminated food or water [21]. The high rate of emergence and dissemination of antimicrobial-resistant Campylobacter organisms is due to large-scale indiscriminate use of antimicrobials in animal agriculture and antibiotic abuse in humans $[22,23]$. Consequently, edible tissues from food animals may become vehicles for the transmission of antimicrobial-resistant Campylobacter strains to humans through the consumption of the undercooked tissues $[3,7]$.

The epidemiology of TCI in poultry in Nsukka agricultural zone is not well understood due to dearth of data on the prevalence and risk factors of the infection. Research findings elsewhere [11,24] indicated that the age of birds at slaughter, rearing of other animals within poultry farm premises and heavy rainfall shortly before slaughter are risk factors for Campylobacter infection in poultry. However, it is not clear whether these factors apply in the study area. Furthermore, the specific role or contribution of poultry to the overall Campylobacter burden has not been elucidated in the study area, despite large-scale production and consumption of poultry and poultry products.

Despite a few reports on Campylobacter in some parts of the country [25-27], campylobacteriosis has remained a neglected zoonosis [28] due to a lack of epidemiological information on the transmission dynamics. Furthermore, there is no existing national surveillance program or database information relating to Campylobacter infections in food animals in Nigeria.
This study determined the prevalence and risk factors for TCI in poultry. This will highlight the current status of the infection and aid a better understanding of Campylobacter transmission mechanism in Nsukka agricultural zone. The study may also guide policy formulation in the selection of appropriate control measures and institutions of public health action against TCI in view of the health and economic consequences thereof.

\section{Materials and Methods}

\section{Ethical approval}

Ethical approval is not applicable to this study as only stool samples from poultry were used in this study.

\section{Informed consent}

Oral consent to partake in the study was requested and obtained from poultry farmers included in this study.

\section{Study location}

The study was carried out in Nsukka agricultural zone of Enugu State, Southeast, Nigeria. The zone is the largest of the three agricultural zones of the state, with map coordinates of $6^{\circ} 51^{\prime} 24^{\prime \prime} \mathrm{N}$ and $7^{\circ} 23^{\prime} 45^{\prime \prime} \mathrm{E}$ [29]. The study location has a total land area of about $5545.38 \mathrm{~km}^{2}$ and a population of about 2.5 million people $[22,23]$. Nsukka is characterized by two tropical climatic seasons: Wet/rainy (winter) and dry/hot (summer); low relative humidity of $14 \%$, an annual mean rainfall range of $168-170 \mathrm{~mm}$, and preponderance of Guinea savannah vegetation [30]. Although the majority of Nsukka citizenry are involved in crop farming and civil service, subsistent food animal production, especially poultry farming, is extensively practiced, to augment income or as precaution against crop yield failure.

\section{Study design}

The study adopted a cross-sectional study design, consisting of two phases. The first phase involved the use of a structured questionnaire to obtain information bordering on sociodemographics of the farmers, biosecurity practices adopted in poultry farms, and the farmers' involvement in practices that exacerbate colonization and transmission of TCI in poultry. Sixty poultry farmers, one per farm, who consented to partake in the study, and were either the farm owners or manager, were randomly selected and surveyed. The second phase was isolation of TCOs, according to standard microbiological method, to determine the prevalence of TCI in poultry and poultry farms in the study area.

\section{Sample collection}

Although 299 fecal samples were calculated as the minimum sample size [31] based on $36 \%$ prevalence reported by Akwuobu et al. [32], a total of 640 fecal samples were used in this study for buoyancy and accuracy of data. In the 60 randomly selected farms, 30 farms each were surveyed during the dry 
and wet seasons. Stool samples were aseptically collected directly from the cloacae in $5-25 \%$ of chicken reared, using sterile swab sticks. Epidemiological variables such as farm location, season, type of poultry, sex, and flock size were determined and recorded. Thereafter, the fecal samples were transported in ice-packed container, within $1 \mathrm{~h}$ of collection, to the diagnostic laboratory of Veterinary Microbiology Department, University of Nigeria, Nsukka, for the bacteria isolation.

\section{Isolation of thermophilic Campylobacter species}

The fecal samples were plated directly on modified charcoal cefoperazone deoxycholate agar (mCCDA, CMO739, Oxoid, UK) for the Campylobacter isolation. The agar (mCCDA) was prepared according to the manufacturer's instruction and supplemented with mCCDA selective supplement (SRO 155E, Oxoid, UK) before plating. The setup was then incubated under microaerophilic conditions, generated by CampyGen ${ }^{\circledR}(\mathrm{CN} 0025 \mathrm{~A}$, Oxoid, UK) at $42^{\circ} \mathrm{C}$ for $48 \mathrm{~h}$, as already described [26]. Suspected thermophilic Campylobacter colonies appearing flat, glossy, and thinly spreading on the agar surface were sub-cultured on supplemented agar as described by Nwankwo et al. [12] to obtain a pure culture. Subsequently, putative pure colonies were subjected to biochemical characterization as described by Barrett et al. [33]. Colonies that tested positive during biochemical characterization were also Gram-stained and viewed for Gram-negative short rods, in oil immersion at $100 \times$ objective for confirmation.

\section{Statistical analysis}

Completed copies of the questionnaires were retrieved and the responses collated for statistical analysis. Fisher's exact test was performed to check for significant association $(\mathrm{p}<0.05)$ between TCI in poultry and farm location, type of poultry, sex, season, and flock size. The statistic was also used to determine whether there is a significant association $(p<0.05)$ between Campylobacter infection in poultry and farm practices and epidemiological variables that could enhance dissemination of the infection and hence constitute the risk factors or determinants of TCI. Casual association between the infection and farm practices or epidemiological variables was established at $\mathrm{p}<0.05$ and/or odds ratio values $>1$. The tests were performed at 5\% probability level using GraphPad Prism ${ }^{\circledR}$ version 6.04 (GraphPad ${ }^{\circledR}$ Inc., San Diego, California, USA).

\section{Results}

\section{Demographics and socioeconomic characteristics of respondents}

Majority of the farm owners or managers were males aged $<45$ years $(76.7 \%, 46 / 60)$. In addition to poultry keeping, most of the farmers reared other food animals, such as pig $(38.4 \%, 23 / 60)$, small ruminants $(35 \%, 21 / 60)$, fish $(20 \%, 12 / 60)$, and cattle $(7.7 \%, 4 / 60)$; while $15.4 \%$ kept dog or cat as biological control for rodents or security in the farm. About 68\% (41/60) of the farmers had a flock size of $<100$ birds. About 5\% (3/60) of the farmers had no formal education; while $41.7 \%(25 / 60), 40 \%(24 / 60)$, and $13.3 \%(8 / 60)$ of the respondents attained basic (primary), post-primary (secondary), and tertiary educational levels, respectively.

\section{Management and biosecurity practices adopted in poultry farms surveyed}

Table-1 contains the result of husbandry systems and biosecurity measures implemented in poultry farms surveyed. Majority of the farms $(93.3 \%, 56 / 60)$

Table-1: Husbandry and biosecurity practices adopted in poultry farms $(n=60)$ surveyed in Nsukka agricultural zone, Nigeria.

\begin{tabular}{llc}
\hline Variables & Characteristics & Number of farms (\%) \\
\hline Husbandry systems & Intensive & $56(93.3)$ \\
& Semi-intensive & $4(5.0)$ \\
Type of intensive & Traditional (extensive) & $1(1.7)$ \\
system & Deep litter & $49(87.6)$ \\
Biosecurity measures & Battery cage & $7(12.5)$ \\
practiced & Availability of perimeter fencing & $21(35.0)$ \\
& Control of intrusion of wild or migratory birds into the farm & $18(30.0)$ \\
& Sanitization of drinking water & $19(31.7)$ \\
& Screening of poultry houses with net & $29(48.3)$ \\
& Practiced all-in-all-out stock replacement program & $34(56.7)$ \\
& Quarantine of incoming or exposed animals & $18(30.0)$ \\
& Enforcement of unidirectional movement in the farm & $14(23.3)$ \\
& Farm sited about 200 m away from residential areas and water & $13(21.7)$ \\
& bodies & \\
& Practiced occasional fumigation & $6(10.0)$ \\
& Availability of functional rodents control programs & $10(16.7)$ \\
& Availability of hand washing facilities at farm entrances & $8(13.3)$ \\
& Use of only new or disinfected egg crates in the farm* & $2(3.9)$ \\
& Availability of functional foot dips at farm and pen entrances & $11(18.3)$
\end{tabular}

*Not applicable to nine farms that did not rear laying birds 
practiced intensive management system of poultry production, either as deep litter $(87.6 \%, 49 / 56)$ or battery case system $(12.5 \%, 7 / 60)$. Several biosecurity practices and various levels of compliance were observed (Table-1). Prominent among the practices is routine vaccination against endemic poultry diseases, practiced in $88.3 \%(53 / 60)$ of the farms surveyed.

\section{Prevalence of thermophilic Campylobacter}

Farm and individual prevalence of $78.3 \%(47 / 60)$ and $19.4 \%(124 / 640)$, respectively, were recorded for TCI. The prevalence of $15.7 \%(54 / 343)$ and $23.6 \%$ $(70 / 297)$ were found for birds reared in urban and rural areas, respectively (Table-2). Similarly, the prevalence rates of $17.2 \%(79 / 460), 25 \%(45 / 180), 14.7 \%$ (49/334), and $24.5 \%$ (75/306) were documented for broiler, layer, male and female birds, respectively (Table-2). Thermophilic Campylobacter species were isolated from $23.9 \%(68 / 285)$ and $15.8 \%(56 / 355)$ of the fecal samples during the wet and dry seasons, respectively. Significant association $(p<0.05)$ existed between TCI and farm location, type of poultry, sex, and season; but none was found at $\mathrm{p}=0.548$ between the bacterial infection and flock size (Table-2).

\section{Risk factors for thermophilic Campylobacter infection}

Table- 3 contains the results on risk factors for TCI in poultry farms surveyed. Major risk factors found and the proportions of farms involved were non-sanitization of drinking water $68.3 \%(41 / 60)$, rearing other animals alongside poultry $85 \%(51 / 60)$, non-quarantine of exposed or incoming birds 70\% (42/60), keeping birds of different ages together 61\% (37/60), thinning (partial depopulation of flock) $53.5 \%$ (32/60), overstocking $43.3 \%(26 / 60)$, and presence of rodents and/or wild

Table-2: Prevalence of thermophilic Campylobacter infection in poultry farms $(n=60)$ surveyed in Nsukka agricultural zone, Nigeria.

\begin{tabular}{|c|c|c|c|c|c|c|}
\hline $\begin{array}{l}\text { Epidemiological } \\
\text { variables }\end{array}$ & $\begin{array}{c}\text { Number of } \\
\text { sampled }\end{array}$ & $\begin{array}{c}\text { Number of } \\
\text { positive }\end{array}$ & Prevalence & Odds ratio & $\begin{array}{c}95 \% \text { confidence } \\
\text { interval }\end{array}$ & p-value \\
\hline \multicolumn{7}{|l|}{ Farm locations } \\
\hline Urban areas & 343 & 54 & 15.7 & 0.6 & $0.41-0.9$ & $0.0159 *$ \\
\hline Rural areas & 297 & 70 & 23.6 & & & \\
\hline \multicolumn{7}{|l|}{ Types of poultry } \\
\hline Broiler & 460 & 79 & 17.2 & 0.622 & $0.41-0.94$ & $0.0265^{*}$ \\
\hline Layer & 180 & 45 & 25 & & & \\
\hline \multicolumn{7}{|l|}{ Sex } \\
\hline Male & 334 & 49 & 14.7 & 0.53 & $0.36-0.79$ & $0.0019 *$ \\
\hline Female & 306 & 75 & 24.5 & & & \\
\hline \multicolumn{7}{|l|}{ Season } \\
\hline Wet & 285 & 68 & 23.9 & 1.67 & $1.13-2.48$ & $0.0118 *$ \\
\hline Dry & 355 & 56 & 15.8 & & & \\
\hline \multicolumn{7}{|l|}{ Flock size } \\
\hline$<100$ birds & 298 & 61 & 20.5 & 1.14 & $0.77-1.69$ & 0.5480 \\
\hline$\geq 100$ birds & 342 & 63 & 18.4 & & & \\
\hline
\end{tabular}

*Denotes statistically significant $\mathrm{p}$-value, Fishers' exact test

Table-3: Risk factors for thermophilic Campylobacter infection in poultry farms $(n=60)$ survey in Nsukka agricultural zone, Nigeria.

\begin{tabular}{|c|c|c|c|c|c|c|}
\hline Risk practices & $\begin{array}{c}\text { Number of farms } \\
\text { involved }\end{array}$ & $\begin{array}{c}\text { Number of farms } \\
\text { infected }\end{array}$ & $\begin{array}{c}\text { Proportion } \\
(\%)\end{array}$ & Odds ratio & $95 \% \mathrm{CI}$ & p-value \\
\hline \multicolumn{7}{|c|}{ Non-sanitization of drinking water } \\
\hline Yes & 41 & 36 & $68.3(41 / 60)$ & 5.24 & $1.42-19.3$ & $0.0164 *$ \\
\hline No & 19 & 11 & & & & \\
\hline \multicolumn{7}{|c|}{ Rearing of other animals alongside poultry } \\
\hline Yes & 51 & 42 & $85(51 / 60)$ & 3.73 & $0.83-16.7$ & 0.0917 \\
\hline No & 9 & 5 & & & & \\
\hline \multicolumn{7}{|c|}{ Non-quarantine of exposed or incoming birds } \\
\hline Yes & 42 & 35 & $70(42 / 60)$ & 2.5 & $0.7-8.93$ & 0.1811 \\
\hline No & 18 & 12 & & & & \\
\hline \multicolumn{7}{|c|}{ Rearing of birds of different ages } \\
\hline Yes & 37 & 31 & $61(37 / 60)$ & 2.26 & $0.65-7.86$ & 0.2148 \\
\hline No & 23 & 16 & & & & \\
\hline \multicolumn{7}{|c|}{ Presence of rodents and or wild birds in the farm } \\
\hline Yes & 24 & 20 & $40(24 / 60)$ & 1.67 & $0.45-6.19$ & 0.5336 \\
\hline No & 36 & 27 & & & & \\
\hline \multicolumn{7}{|c|}{ Thinning (partial depopulation of the flock) } \\
\hline Yes & 32 & 29 & $53.5(32 / 60)$ & 5.37 & $1.30-22.2$ & $0.0256 *$ \\
\hline No & 28 & 18 & & & & \\
\hline \multicolumn{7}{|c|}{ Overstocking/overcrowding } \\
\hline Yes & 26 & 24 & $43.3(26 / 60)$ & 5.74 & $1.14-28.8$ & $0.0280 *$ \\
\hline
\end{tabular}

*Denotes statistically significant $\mathrm{p}$-value, Fishers' exact test 
birds in the farm $40 \%(24 / 60)$. Significant association $(p<0.05)$ was noted between the bacteria colonization of poultry and non-sanitization of drinking water, thinning, and overstocking.

\section{Discussion}

Mostly (76.7\%) young people were involved in poultry rearing, probably due to the high level of acceptance of poultry products across diverse ethnic backgrounds and religious beliefs. In addition, poultry production provides the highest turnover rate and the quickest returns on investment in the livestock subsector [34]. Hence, poultry farming has become a major animal protein-deficient gap filler and a very important aspect of the national economy, contributing substantially to job creation, poverty alleviation, and crime reduction, despite the attendant public health risks thereof.

The $19.4 \%$ overall prevalence found is significant, given that Campylobacter infection is a major threat to public health $[34,35]$ and human health is intricately connected to that of animals. Concerted effort should be made to limit human exposure to the infection through food chain or contact with an infected animal. Good farm management practices such as intensive husbandry system and strict biosecurity are pivotal to curtail dissemination of pathogens of public health importance at the farm level. Since poultry is a potent source of human Campylobacter infection $[8,11,35,36]$, proper treatment of poultry feces before disposal or use as feed (in piggeries or fisheries) or manure (in vegetable and fruit gardens) may be an effective control measure against the spread of these enteric zoonotic pathogens. As wild bird feces can contaminate the environment [37], adequate environmental sanitation and hygiene, especially in public places, neighborhoods, and recreational centers, should be prioritized, to restrict the proliferation of the agents in the environment and the possible onward transmission to humans.

The $19.4 \%$ prevalence is lower than $36 \%$ prevalence previously reported in the same study area about a decade ago [32]. This shows that the infection is on the decline. The decline may be attributed to the husbandry management system as most farms (93.3\%) have now adopted intensive husbandry system of poultry production in the study area. Intensive husbandry management system has the advantage of low pathogen infectivity as against the extensive or freerange (organic) system that predisposes to diseases, especially in the tropics. Under intensive management system, the animals are shielded from climatic and certain epidemiological factors that facilitate acquisition and spread of infection in animal farms [38].

In addition, prophylactic administration of antibiotics, widely practiced in poultry farms nationwide [22], may have contributed in reduction of Campylobacter colonization of the animals in the farms surveyed. Given that, TCI does not usually result in clinical manifestation of disease in animals, and hence, antibiotics treatment may not be warranted; administration of antimicrobial agents for therapeutic or chemoprophylactic treatment of other invasive infections may help depopulate non-targeted organisms such as Campylobacter species. The resultant effect, therefore, is a reduction in colonization of poultry with TCOs, but the risks of the zoonotic transmission and development of antibiotics resistant strains of Campylobacter species still subsist [21].

The overall prevalence is also lower than the previous findings $[7,12,25]$, in which the prevalence rates of $38.8 \%, 81.9 \%$, and $30 \%$ were reported in other parts of the country. Furthermore, the prevalence of $23.9 \%$ and $15.8 \%$ found during the wet and dry seasons, respectively, in the study area differs from $30 \%, 31 \%$, and $25 \%$ which were reported during wet, cold dry, and hot seasons in Sokoto, Northwest Nigeria [21]. The differences in the findings could be attributed to discrepancies in climatic or epidemiological factors at the various study locations, including husbandry systems, season, and health status of the animals. In addition, disparities in the researcher's experiences and capabilities in the bacterial isolation and characterization processes can be determining factors. The total number of samples investigated can influence the accuracy of research outcomes.

Higher prevalence of Campylobacter infection in layers $(25 \%)$ than broilers $(17.2 \%)$ may be attributed to coprophagia and pecking of vents which are common in layers. These attributes predispose to TCI or other infections transmitted through the feco-oral route. In addition, layers are usually kept for a longer period in the farm than other birds. The extended period of stay in the farm exposes them to Campylobacter infection much more than the broilers usually reared for 6-9 weeks. Furthermore, stress associated with egg production and hatching, which laying birds, usually undergo, tends to lower their immunity and predisposes them to infectious agents like TCOs.

Although it has been adjudged low, 19.4\% overall prevalence is high and very significant from public health and food safety points of view. Thermophilic Campylobacter colonization of one in every five poultry reared in the study area portents great public health risk; as poultry and poultry products are cherished and widely accepted across the board in the study area. The use of pets (dog and cat) for biological control of rodents or for security purposes in the farms may facilitate Campylobacter infection of the pets for onward transmission to humans. The significance of the finding is that the contamination of poultry meat during processing may be high, and humans may easily acquire the infection through the consumption of undercooked poultry products or contact with infected birds at the poultry-human interface.

In addition, the significance of Campylobacter colonization of poultry entails not only contamination 
of poultry products during processing but also drinking water sources through contamination of surface and subsurface water during disposal of slaughterhouse waste, effluents, and meat offal. Campylobacter organisms have been reported to survive in animal dung for over 10 months [39]. Furthermore, such environment contaminated with fecal matters from live chicken has been associated with the development of childhood diarrhea, especially in developing countries, where Campylobacter is hyperendemic $[7,40]$.

\section{Conclusion}

High prevalence of Campylobacter infection in poultry, relished by all and sundry in the study area, portends great public health risks; as the infection can easily be transmitted to humans at the poultry-human interface and through the food chain. In view of the need to achieve optimum health for humans, animals, and the environment; strict biosecurity in poultry farms surveyed is imperative to curb TCI in poultry and hence the risk of human infection and the resultant public health and economic consequences.

\section{Authors' Contributions}

EON conceived and designed the study. ION and JCU collected and analyzed the samples. EON designed the questionnaire and carried out the statistical analysis. ION drafted the manuscript and EON revised it. All authors read and approved the manuscript.

\section{Acknowledgments}

The researchers did not receive financial assistance from any quarter. However, they are grateful to the laboratory staff of Veterinary Pathology and Microbiology and that of Veterinary Public Health and Preventive Medicine, University of Nigeria, Nsukka, for their technical assistance. The authors are particularly grateful to Prof. K.F. Chah for his useful suggestions and the provision of laboratory consumables during the study.

\section{Competing Interests} interests.

The authors declare that they have no competing

\section{Publisher's Note}

Veterinary World (Publisher of International Journal of One Health) remains neutral with regard to jurisdictional claims in published institutional affiliation.

\section{References}

1. SkarpCPA, Hänninen ML, Rautelin HIK. Campylobacteriosis: The role of poultry meat. Clin Microbiol Infect 2016;22:103-9.

2. Szczepanska B, Andrzejewska M, Spica D, Klawe JJ. Prevalence and antimicrobial resistance of Campylobacter jejuni and Campylobacter coli isolated from children and environmental sources in urban and suburban areas. BMC Microbiol 2017;17:80.

3. Modi S, Brahmbhatt MN, Chatur YA, Nayak JB. Prevalence of Campylobacter species in milk and milk products, their virulence gene profile and anti-bio gram. Vet World 2015;8:1-8.

4. Vandamme P, Debruyne L, De Brandt E, Falsen E. Reclassification of Bacteroides ureolyticus as Campylobacter ureolyticus comb. nov., and emended description of the genus Campylobacter. Int J Syst Evol Microbiol 2010;60:2016-22.

5. Uaboi-Egbenni PO, Bessong PO, Samie A, Obi CL. Prevalence and antimicrobial susceptibility profiles of Campylobacter jejuni and coli isolated from diarrheic and non-diarrheic goat feces in Venda region, South Africa. Afr J Biotechnol 2011;10:14116-24.

6. Sahin O, Yaeger M, Wu Z, Zhang Q. Campylobacter associated diseases in animals. Annu Rev Anim Biosci 2017;5:21-42.

7. Salihu MD, Junaidu AU, Magaji AA, Abubakar MB, Adamu AY, Yakubu AS. Prevalence of Campylobacter in poultry meat in Sokoto Northwestern Nigeria. J Public Health Epidemiol 2010;1:41-5.

8. Ngulukun S, Oboegbulem S, Klein G. Multilocus sequence typing of Campylobacter jejuni and Campylobacter coli isolates from poultry, cattle and humans in Nigeria. J Appl Microbiol 2016;121:561-8.

9. Sahin O, Fitzgerald C, Stroika S, Zhao S, Sippy RJ, Kwan P, et al. Molecular evidence for zoonotic transmission of an emergent, highly pathogenic Campylobacter jejuni clone in the United States. J Clin Microbiol 2012;50:680-7.

10. Nwankwo IO, Faleke OO, Salihu MD, Magaji AA. Prevalence of Campylobacter species in out-patients and pregnant women attending Government clinics in Sokoto, Nigeria. J Prev Med Care 2016;1:8-15.

11. Torralbo A, Borge C, Allepuz A, García-Bocanegra I, Sheppard SK, Perea A, et al. Prevalence and risk factors of Campylobacter infection in broiler flocks from Southern Spain. Prev Vet Med 2014;114:106-13.

12. Nwankwo IO, Faleke OO, Salihu MD, Musa U, Magaji A, Audu B, et al. Prevalence and molecular identification of Campylobacter species isolates from poultry and humans in Sokoto, Nigeria. Sokoto J Vet Sci 2017;15:1-8.

13. Okoli CE, Njoga EO, Enem SI, Godwin EE, Nwanta JA, Chah KF. Prevalence, toxigenic potential and antimicrobial susceptibility profile of Staphylococcus isolated from ready-to-eat meats. Vet World 2018;11:1214-21.

14. Onunkwo JI, Njoga EO, Njoga UJ, Ezeokafor E, Ekere SO. Brucella seropositivity in chicken and risk factors for Brucella infection at the animal-human interface in Anambra State, Nigeria. Int J One Health 2018;4:28-34.

15. Ugboma AM, Salihu MD, Magaji AA, Abubakar MB. Prevalence of Campylobacter species in ground water in Sokoto, Sokoto State, Nigeria. Vet World 2013;6:285-7.

16. Ngulukun SS, Oboegbulem SI, Fagbamila I, Barde I. Antimicrobial resistance of Campylobacter jejuni and Campylobacter coli isolated from chickens in a diagnostic laboratory. Afr J Microbiol Res 2015;9:2297-01.

17. Ajene AN, Fischer Walker CL, Black RE. Enteric pathogens and reactive arthritis: A systematic review of Campylobacter, Salmonella and Shigella associated reactive arthritis. J Health Popul Nutr 2013;31:299-307.

18. Esan OB, Pearce M, van Hecke O, Roberts N, Collins DRJ, Violato $\mathrm{M}$, et al. Factors associated with sequelae of Campylobacter and non-typhoidal Salmonella infections: A systematic review. EBioMedicine 2017;15:100-11.

19. Wieczorek K, Szewczyk R, Osek J. Prevalence, antimicrobial resistance and molecular characterization of Campylobacter jejuni and C. coli isolated from retail meat in Poland. Vet Med 2012;57:293-9.

20. Salihu MD, Junaidu AU, Magaji AA, Yakubu Y. Prevalence and antimicrobial resistance of thermophilic Campylobacter isolates from broiler flock in Sokoto, Nigeria. J Vet Sci 2012;5:51-8

21. Nwankwo IO, Salihu MD, Faleke OO, Magaji AA, Garba J. 
Seasonal variation in prevalence and antimicrobial resistance of Campylobacter species isolates from the feces of free range chickens and humans in Sokoto, North western Nigeria. Anim Sci Rep 2018;11:11-21.

22. Njoga EO, Onunkwo JI, Okoli CE, Ugwuoke WI, Nwanta JA, Chah KF. Assessment of antimicrobial drug administration and antimicrobial residues in food animals in Enugu State, Nigeria. Trop Anim Health Prod 2018;50:897-902.

23. Njoga EO, Onunkwo JI, Ekere SO, Njoga UJ, Okoro WN. Seroepidemiology of equine brucellosis and role of horse carcass processors in the spread of Brucella infection in Enugu State, Nigeria. Int J Curr Res Rev 2018;10:39-45.

24. Jonsson ME, Chriél M, Norström M, Hofshagen M. Effect of climate and farm environment on Campylobacter spp. colonisation in Norwegian broiler flocks. Prev Vet Med 2012;107:95-104.

25. Salihu MD, Junaidu AU, Oboegbulam SI, Egwu GO, Magaji AA, Abubakar MB, et al. Prevalence of Campylobacter spp. in Nigeria indigenous chicken in Sokoto State Northwestern Nigeria. Int J Vet Med 2008;7:1.

26. Nwankwo IO, Faleke OO, Salihu MD, Magaji AA, Musa U, Garba J, et al. Detection and viability of Campylobacter species isolates from different species of poultry and humans from Sokoto State, Nigeria. Int J One Health 2016;2:19-23.

27. Nwankwo IO, Faleke OO, Salihu MD, Magaji AA, Musa U, Garba J. Epidemiology of Campylobacter species in poultry and humans in the four agricultural zones of Sokoto State, Nigeria. Public Health Epidemiol 2016;8:184-90.

28. Altekruse SF, Stern NJ, Fields PI, Swerdlow D. Campylobacter jejuni. An emerging foodborne pathogen. Emerg Infect Dis 1999;5:28-35.

29. Obioha FC, Ezenduka E, Ukoha JC, Nwanta JA. Assessment of cadmium $(\mathrm{Cd})$ residues in organs and muscles of slaughtered pigs at Nsukka and environs in Enugu State, Nigeria. J Vet Med Anim Health 2016;8:199-206.

30. Nwanta JA, Shoyinka SV, Chah KF, Onunkwo JI, Onyenwe IW, Eze JI, et al. Production characteristics, disease prevalence, and herd health management of pigs in Southeast Nigeria. J Swine Health Prod 2011;19:331-9.

31. Thrusfield M. Estimation of disease prevalence. In: Veterinary Epidemiology. $2^{\text {nd }}$ ed United Kingdom: Blackwell Science; 1995. p. 182-7.

32. Akwuobu CA, Oboegbulem SI, Ofukwu RA. Characterization and antibiogram of local isolates of Campylobacter species from chicken in Nsukka Area, Southeast Nigeria. Am Eur J Sustain Agric 2010;4:117-21.

33. Barrett TJ, Patton CM, Morris GK. Differentiation of Campylobacter species using phenotypic characterization. J Lab Med 1988;19:96-102.

34. Omolayo JO. Economic analysis of broiler production in Lagos State poultry estate, Nigeria. J Invest Manage 2018;7:35-44.

35. Abulreesh HH, Organji SH, Elbanna K, Osman GE, Almalki MH, Ahmad I. Campylobacter in the environment: A major threat to public health. Asian Pac J Trop Dis 2017;7:374-84.

36. Kovanen S, Kivistö R, Llarena AK, Zhang J, Kärkkäinen UM, Tuuminen $\mathrm{T}$, et al. Tracing isolates from domestic human Campylobacter jejuni infections to chicken slaughter batches and swimming water using whole-genome multilocus sequence typing. Int $\mathrm{J}$ Food Microbiol 2016;226:53-60.

37. Abdollahpour N, Zendehbad B, Alipour A, Khayatzadeh J. Wild-birds feces as a source of Campylobacter jejuni infection's playgrounds in Iran. Food Control 2015;50:378-81.

38. Jatfa JW, Magudu LR, Adenkola AY, Oke PO, Orgem CM. Farm system distribution of gastrointestinal and haemoparasites of pigs within Makurdi metropolis. Sokoto J Vet Sci 2019;16:24-9.

39. Inglis GD, Kalischuk LD. Use of PCR for direct detection of Campylobacter species in bovine feces. Appl Environ Microbiol 2003;69:3435-47.

40. Coker AO, Isokpehi RD, Thomas BN, Amisu KO, Obi CL. Human campylobacteriosis in developing countries. Emerg infect Dis 2002;8:237-44. 